\title{
The Perception of and Adaptation to Climate Change among Cocoa Farm Households in Ondo State, Nigeria
}

\author{
Oluwatusin, Femi Michael \\ Department of Agricultural Economics \& Extension Services, \\ Ekiti State University, P.O.Box, 1258, Ado Ekiti, Nigeria \\ femitusinm@gmail.com
}

\section{Doi:10.5901/ajis.2014.v3n1p147}

\section{Absract}

The study was conducted to examine the perception of and adaptation to climate change among cocoa farmers in Ondo State, Nigeria. Also, determinants of farmers' level of perception and adaptation to change in climatic conditions were examined. Simple random sampling technique was used to select 200 farmers but after removing cases of incomplete or non-response, the final sample size came to 160 cocoa farmers. Descriptive statistics were used to analyse the farmers' socio-economics characteristics while Heckman's two-step procedure was used to identify the determinants of respondents' perception and adaptation to climate change. The results revealed that the cocoa farmers' population was ageing and cocoa production in the study area was dominated by men. The household size ranged between 1 and 20 persons while the mean was 8 persons. The majority of the farmers solely made use of hired labour. The average farm size was 7 hectares while 83.75 percent of cocoa farmers had no access to credit. Most of the respondents perceived climate change in the study area. In order to adapt to climate change, 10 different types of adaptation strategies were used by $83.75 \%$ of the farmers while $16.25 \%$ did nothing. 7 variables (age, education, farming experience, household size, farm size, access to extension services, and distance to farm input purchasing market) significantly determined whether or not cocoa farmers perceive climate change while again another 7 independent variables (age, education, farming experience, farm size, access to extension services, access to credit and training on climate change) significantly determined whether or not they would adapt to it. The study therefore, recommends that credit should be made available to the farmers and an effective extension service system should be put in place.

Keywords: Heckman, perception, adaptation, determinants, Nigeria, climate

\section{Introduction}

The tree crop called Theobroma cacao (Cocoa), a low altitude plant grows from sea level up to an altitude of 700 meters. It requires an annual rainfall level of between $1500 \mathrm{~mm}$ and $2000 \mathrm{~mm}$. Cocoa can be grown best under temperatures between $18-21^{\circ} \mathrm{C}$ mean minimum and $30-32^{\circ} \mathrm{C}$ mean maximum and absolute minimum of $10^{\circ} \mathrm{C}$ (Anim-Kwapong and Frimpong, 2005). Optimum development of cocoa trees requires a humid and hot atmospheric condition. In areas where cocoa grows very well, relative humidity is high. 100 percent relative humidity is recorded during the day while 70-80 percent could be noticed at night. Shading is required in a cocoa tree's early years. The crop needs good soil with a PH in the range of 5.0-7.5. The soil is expected to have a high content of organic matter ( 3.5 percent in the top 15 centimeter) with exchangeable bases amounting to at least 35 percent of the total cation exchange capacity (CEC).

Cocoa was first introduced into Nigeria in the late eighteenth century from the Latin American Continent. Production of cocoa in Nigeria on large scale started around 1890 and the first export was in 1892. Before the discovery of oil, cocoa played a dominant role in the economy of our great nation -Nigeria. This was noticed in the former Western Region, where the crop was responsible for the producer income for a large number of peasant cocoa farmers. The revenue generated from the sales of cocoa enabled the then Western Marketing Board to be in position to provide grants amounting to N157,900 million between 1954 and 1969 to the region. Also, from cocoa revenues, government were able to invest in projects such as; Lepal Estate, Wemabod, Wema Bank, National Bank, etc,. The board also provided funds for the establishment of University of Ife ( Now Obafemi Awolowo University, Ile Ife). In order to ensure availability of trading surpluses, the board normally kept the producer prices below the world prices. In 1965, Nigeria attained the height of being the second largest producer of cocoa in the world. This marked the glorious period for the crop and the economy at large. With the discovery of oil, neglect sets into the industry.

However, despite the neglect, the importance of cocoa to the Nigerian economy cannot be over-emphasized. In recent years, it is the largest non oil foreign exchange earner for the country. In 2012 , Nigeria earned $\$ 900$ million in 
cocoa export (Business Monitor International, 2013). Also, cocoa is a means of conserving foreign exchange. This is done through production of cocoa based products such as cocoa butter and powder which would have been imported. In addition, the use of cocoa beans as raw material by these agro-based industries saves the country from the use of her foreign exchange. In term of employment, the cocoa sector in Nigeria engages millions of smallholders' farm families while over 5 millions farmers, warehouse agents, processors, exporters and licensed buying agents main income is from the sales of cocoa. Nigeria, the world's fourth biggest grower of cocoa, has planned to increase her output of cocoa to 500,000 and 1 million tonne by 2015 and 2018 respectively (Sun Report, 2013). For development, government has targeted cocoa production by setting up National Cocoa Development Committee (NCDC). In order to boost production of cocoa beans, millions of seedlings, fertilizer and other input have been distributed to farmers by the committee.

However, the position of Nigeria in the world concerning production of cocoa in the past has not been restored because at present she is occupying $4^{\text {th }}$ position and producing $5 \%$ of the world's output. Cocoa production takes place mainly in the rainforest area of Nigeria known as the Cocoa belt. 95 percent of cocoa is grown in 210ut of the 36 States by small scale farmers using low inputs and crude implement. The main producing states are, Ondo, Ekiti, Oyo, Osun, Ogun, Akwa Ibom, Cross River, Edo, and Delta. Over 60 percent of the total quantity of cocoa beans produced for local industries and export comes from Ondo State annually (ICCO, 2009).

Over the years, climate change has been noticed to have a considerable effect on agricultural production. It has been observed that every stage of cocoa beans production requires favourable climatic conditions (Nabuurns et al., 2007). Variations in cocoa yield are affected more by rainfall than by any other climatic factors. This crop is very sensitive to a soil water deficiency. Cocoa tree needs well distributed rainfall throughout the growing season. For optimum development of the crop, a hot and humid atmosphere is necessary. Also, cocoa could tolerate acid soils, provided its nutrient content is high. Developing or ripening cocoa pods are affected by black pod disease which is closely related to weather and climate. This disease is more prevalent in damp environment. Its destruction is felt when the short dry period between July and August is wet. Also, the sucking insects, mirids, are more destructive when the moisture deficit is severe between September and March. High light intensity allows the insect to multiply rapidly. The stages and rates of development of cocoa pests and pathogens could be altered by climate change. Therefore, the importance of climate change perception among the cocoa farmers cannot be overemphasized.

Perception could be defined as the accurate view of reality. Perceiving is the process of using the senses to acquire information about the surrounding environment or situation. The basic precondition for adaptation to climate change is perception. The farmers best placed to pronounce on whether climate change has occurred are presumably those who have had the most experience of farming (maddison, 2006). Perception is necessary because only those farmers who perceive change in climate will consider whether to adapt to it or not.

In addition, adaptations are interventions or adjustments which occur in order to take advantage of the opportunities or to manage the losses that take place as a result of any external change. Adaptation is the process of improving society's ability to cope with changes across time scale, from short term to the long term (Tesso et al., 2012). Better still, adaptation in farming to climate change involves action taken by any farm household to capitalize on the positive effects or reduce the negative effects of change in climatic conditions. Adaptive capacity is the ability of a system to adjust to, change (including climate variability and extreme), moderate potential damages, take advantage of opportunities, or cope with the consequences (IPCC, 2001).

Cocoa happened to be a very important cash crop that has in the past been the mainstay of the economy and its production has been hampered by climate change. This could be rekindled by the revitalization of its production. And a precursor to this is the critical analysis of how cocoa farmers in the study area perceive and adapt to climate change. The main objective of this study is to examine the perception of and adaptation to climate change among cocoa farmers in Ondo State. The specific objectives are to: examine the socio-economic characteristics of cocoa farmers; examine the level of perception to climate change; identify various adaptation strategies adopted by farmers to climate change and examine the determinants of farmers' level of perception and adaptation to climate change.

\section{Research Methodology}

\subsection{The Study Area}

The study was carried out in Ondo State, Nigeria. The state which is well endowed with abundant human and natural resources has an estimated land area of about 15,500 square kilometers. The state is bounded on the north by Ekiti and Kogi States, on the west by Ogun and Osun States, on the east by Edo and Delta States and to the south by the Bight of 
Benin and the Atlantic Ocean. The state is made up of eighteen Local Government Areas and lies between latitudes $5^{\circ} 45^{\prime}$ and $7052^{\prime} \mathrm{N}$ and longitudes $4^{\circ} 20^{\prime}$ and $6^{\circ} 05^{\prime}$ E. 2006 census put her population at 3,441,024. Agriculture constitutes the main occupation of the people of the state. This state is the leading cocoa producing state in Nigeria. Cassava, yams and palm produce are other crops grown in the state.

\subsection{Sources of Data}

The primary data which formed the basis of the analysis and write-up for this study were collected from an intensive survey of the study area. The data were collected with the aid of detailed and structured questionnaire with open and close ended questions. Induction training was carried out for the enumerators in order to brief them about the objectives of the study. After the training, test filling of copies of the questionnaire was carried out. The state Ministry of Agriculture and Natural Resources was contacted for the list of cocoa farmers in the state. Simple random sampling technique was used to select 200 farmers from the list provided. In all, about 200 farmers were interviewed but after removing cases of incomplete or non-response, the final sample size came to 160 cocoa farmers. Information retrieved from the farmers includes household characteristics such as: age, marital status, gender, farming experience, credit accessibility, farm size, household size, and educational background. Also, information on enterprise combination, ownership of farmland, perception of farmers on climate change and adaptation strategies adopted were collected from the farmers.

\subsection{Analytical Techniques}

Descriptive analysis such as mean, mode, and percentage were used to analyse the farmers' socio-economics characteristics while Heckman's two-step procedure was used to identify and analyse the determinants of respondents' perception and adaptation to climate change.

\subsubsection{Heckman Two Step Procedure}

Following Tesso et al.(2012) two equations are involved. The first one is referred to as sample selection equation while the second one is the latent regression equation.

The first equation deals with the perception of farmers to climate change. In equation 1 perception is used as the dependent variable while the explanatory variables are the socio-economics characteristics of the farmers. These are: age, education, farming experience, gender, marital status, household size, farm size, access to extension service, access to credit, distance to farm input purchasing market, training on climate change and off-farm work. Respondents were grouped into two categories based on whether they perceive climate change in the right direction or not. Those that perceive climate change in the right direction (that is, those whose perceptions tally with records of weather monitoring stations in the study area) were grouped as 'perceived' and scored one (1) while those with wrong description and unable to perceive climate change were grouped as 'not-perceived' and awarded zero (0). Hence probit model stated below was used to analyse perception to climate change:

$\operatorname{Pr}\left(\varphi_{i}=1 / T, \alpha\right)=\Phi\left[h\left(T_{i}, \alpha\right)\right]+U_{1 i}$

$\varphi_{i}$ is the latent level of utility an household i gets from the climate change perception.

$\mathrm{T}_{i}$ is the vector of independent variable.

a vector of coefficients to be estimated.

$U_{1}$ is the error term.

$\Phi$ is standard normal cumulative distribution function

The latent regression equation which is referred to as adaptation to climate change model was conditioned on the sample selection equation to cater for the determinants of adaptation strategies to climate change. The model is stated as follows:

$$
E\left(Y_{i} / \varphi_{i}=1\right)=f\left(x_{i}, \beta\right)+\gamma_{i} \frac{\emptyset\left(T_{i} \delta\right)}{\Phi\left(T_{i} \delta\right)}
$$

$\mathrm{E}=$ expectation of taking adaptive measures

$Y_{i}=$ the (continuous) extent of adaptation to climate change

$\gamma_{i}=$ extent to adaptation to climate change

$x_{i}=$ vector of explanatory variables

$\beta=$ vector of coefficient to be estimated

$\varnothing=$ normal probability density function 
Other variables are as earlier defined.

From equation $1, \gamma$ was estimated using $\varphi_{i}$ and $T_{i}$ from whole sample and then the inverse mills ratio $\Lambda$ was computed using equation 3 below:

$$
\begin{aligned}
& \frac{\phi\left(T_{i} \delta\right)}{\Phi\left(T_{i} \delta\right)}=\Lambda \ldots \ldots \ldots \ldots \ldots \ldots . . . . . . . . \\
& \gamma_{i}=\Lambda_{i}\left(\Lambda_{i}-T_{i} \delta\right) \ldots
\end{aligned}
$$

Substituting equation 3 into equation 2 we have:

$Y_{i}^{\bullet}=X_{j}^{\prime} \beta+\gamma_{i} \Lambda+U_{2 j}$

$X_{j}^{\prime}$ is $\mathrm{K}$ vector of independent variables(age, education, farming experience, gender, marital status, household size, farm size, access to extension service, access to credit, distance to farm input purchasing market, training on climate change and off-farm work.)

$Y_{i}^{\bullet}$ is the dependent variable. This is the proportion of adaptation measures adopted by farmer $\mathrm{i}$.

$\mathrm{U}_{2 \mathrm{j}}$ is the error term and other variables are as earlier defined.

In the study area ten (10) different types of adaptation measures were adopted by respondents. Farmers were scored between 0 and 1 based on the proportion of measures adopted.

Using the Heckman procedure in STATA, full maximum likelihood method was used to estimate equations 1 and 5 jointly (Tesso et al. 2012).

\section{Results and Discussion}

\subsection{Respondents' Socio-Economic Charateristics}

Socio-economic characteristics of respondents are presented in Table 1. According to this table, 5 respondents constituting about 3.12 percent of the age distribution were below 30 years of age while about 9.38 percent of the cocoa farmers were between 31 and 40 years of age. Also 25 percent fell within the age range of $41-50$ years. 37.50 percent were between 51 and 60 years and those above 60 years were just 25 percent. The age of the farmers ranged between 27 and 90 years while the majority (62 percent) was above 50 years. With the mean age of 52 years, the age distribution clearly shows that the cocoa farmers' population is ageing. This may be so because cocoa is a tree crop that involves a lot of drudgery in its operations and maintenance. It is only the ageing population that can afford the patience needed in production of cocoa. The younger population are just too inpatient to be tied down to such tedious and time consuming operations. The implication of this age distribution is that most of the farmers may not be willing to adopt new technologies and strategies due to their age and farming experience. Older farmers are highly conservative and most of the time not ready to accept innovations. The age of the farmer dictates the quality and quantity of work to be done on the farm. Aged farmers are found to employ hired labours that are expensive to do most of the tedious job on the farm.

In addition, Table 1 shows that 93.75 percent of the farmers interviewed were men while just 6.25 percent were women. This is an indication that cocoa production is dominated by men and this is so because of the nature of operations involved in its production. Women are more useful during cocoa harvesting. During the survey, it was revealed that those 10 women among the respondents inherited the cocoa farms from their parents. The implication of this is that, cocoa farms are owned mainly by men. This result corroborate one of the findings of Muhammad-Lawal et al(2009) that the sex of an individual determines the type and quality of work he/she does.

Table 1: Distribution of respondents by socio-economics characteristics

\begin{tabular}{lcc}
\hline \multicolumn{1}{c}{ Characteristics } & Frequency & Percentage \\
\hline Age (year) & & \\
Below 30 & 5 & 3.12 \\
$31-40$ & 15 & 9.38 \\
$41-50$ & 40 & 25 \\
$51-60$ & 60 & 37.50 \\
Above 60 & 40 & 25 \\
Gender & & \\
Male & 150 & 93.75 \\
Female & 10 & 6.25 \\
Marital Status & & \\
\hline
\end{tabular}




\begin{tabular}{lcc}
\hline Single & 4 & 2.50 \\
Married & 150 & 93.75 \\
Divorced \\
$\begin{array}{l}\text { Household Size (number) } \\
\text { Below 5 }\end{array}$ & 6 & 3.75 \\
6-10 & 30 & 18.75 \\
$11-15$ & 35 & 21.87 \\
Above 15 & 80 & 50 \\
Labour Availability & 15 & 9.38 \\
Hired labour & & \\
Family labour & 90 & 56.25 \\
Family \& hired labour & 27 & 16.88 \\
Faming experience (year) & 43 & 26.87 \\
Below 20 & & \\
21-40 & 14 & 8.75 \\
41-60 & 76 & 47.50 \\
Above 60 & 45 & 28.12 \\
Educational background & 25 & 15.63 \\
No formal education & & \\
Primary education & 10 & 6.25 \\
Secondary education & 43 & 26.87 \\
Tertiary education & 90 & 56.25 \\
Farm size(Hectare) & 17 & 10.63 \\
Less than 6 & & \\
6-10 & 31 & 19.38 \\
11-15 & 80 & 50 \\
Above 15 & 27 & 16.87 \\
Credit facility & 22 & 13.75 \\
Not available & & \\
Available & 150 & 93.75 \\
\hline & 10 & 6.25 \\
\hline & & \\
\hline
\end{tabular}

\section{Source: Field Survey}

As shown in Table 1, the majority (93.75percent) of the cocoa farmers were married while just 2.50 percent and 3.75 percent were single and divorced respectively. In Nigeria to some extent, marital status determines the household size. Married farmers are expected to have household members that would most of the time assist in farming activities.

In Table 1, the household size distribution of respondents revealed that those that had less than 5 persons were 18.75 percent while those with 6 - 10 persons were 21.87 percent and 50 percent had 11 -15 household size. 9.38 percent had more than 15 persons. The household size ranged between 1 and 20 persons while the mean was 8 persons. This is an indication of large family size in the study area. Household size dictates the number of family labour that would be available for farming activities and a times signifies the size of cocoa farm of an individual farmer.

Table 1 also presents the labour utilization pattern of the cocoa farming households. 56.25 percent (majority) of the farmers solely made use of hired labour while just 16.88 percent depended only on family labour. 26.87 percent combined both family and hired labour for their cocoa production and other farming activities. In the study area the use of more hired labour may be due to the fact that farmers prefer to send their children to school. These children are only available to help their parents during the holidays.

More also, Table 1 shows that about 8.75 percent of respondents had below 20 years experience as cocoa farmers while the majority, 47.50 percent had between 21 and 40 years of farming experience. 45 farmers constituting about 28.12 percent were into cocoa farming between $41-60$ years. Few (15.63 percent) respondents had just above 60 years experience. On the average, a typical cocoa farmer had an experience of about 36 years. It can be deduced that most of the farmers are well experienced and this is necessary for cocoa production. Farming experience could be an index of the degree to which the farmer has been exposed to the existing farm practices and technology and, perhaps, the degree of his willingness to accept new innovation.

In terms of educational level of respondents, Table 1 shows that 6.25 percent of the farmers did not have formal education while 26.87 percent passed through primary education. The majority, 56.25 percent went through secondary education and just 10.63 percent had tertiary education. This is an indication that most of the farmers are educated and can read and write. Farmers with high level of literacy tend to be more efficient in production and readily accept new innovation when compared with the illiterate ones that rely on their experience. 
Land in the study area is very scarce commodity. Most of the lands suitable for agriculture are owned by one family or the other. It is very difficult to acquire land for the cultivation of permanent crop like cocoa. It is their belief that once a land is given out to somebody outside the family for cultivation of tree crops, such land is lost forever by the family. Apart from the land tenure system in the area, the labour intensive nature of producing cocoa does not permit cocoa production on a large scale. Farm size distribution in Table 1 shows that the majority (50 percent) had between 6-10 hectares of land for cocoa production while 19.38 percent cultivated less than 6 hectares of land. This is followed by 11-15 hectares and above 15 hectares cultivated by 16.85 and 13.75 percent respectively. The average farm size was 7 hectares while the minimum and maximum were 0.4 and 25 hectares respectively. Farm sizes are generally small in the study area. This will have effect on the social status of the farmers in the society.

Capital is the most scare resources in a traditional agricultural economy. Cash as one of the factors of production is very hard to come by. Farmers find it difficult to obtain credit and their uncertainties and determination to avert risk make them even less willing to work on borrowed capital. Table 1 shows that the majority (83.75 percent) of the cocoa farmers had not been able to obtain credit in any form since they started growing cocoa while just 16.25 percent had access to credit. This is an indication that credit is still one of the constraining factors of production that needs proper attention.

Most of the Nigerian cocoa farmers have not been known to enjoy monocroping of whatever nature. Cocoa trees are interplanted with a variety of crops such as, coffee, citrus, plantain

Table 2: Response of respondents on enterprise combination

Source: Field Survey

\begin{tabular}{ccc}
\hline Response & Frequency & Percentage \\
\hline Yes & 150 & 93.75 \\
No & 10 & 6.25 \\
\hline Total & 160 & 100 \\
\hline
\end{tabular}

cocoyam, etc. Table 2 shows that 93.75 percent of respondents intercropped cocoa trees with one or two crops on their farms while just few (6.25 percent) did not. Apart from interplanting, the farmers owned several small food crop plots around the cocoa plots where food crops like yam, maize, cassava and vegetable were grown. They engaged in these other enterprises for subsistence while relying on cocoa mainly for income. A times intercropping could have the advantage of keeping weeds growth in check.

Table 3: Distribution of cocoa farmers on the ownership of the farm

Source: Field Survey

\begin{tabular}{ccc}
\hline Response & Frequency & Percentage \\
\hline Tenant & 40 & 25 \\
Owner & 120 & 75 \\
\hline Total & 160 & 100 \\
\hline
\end{tabular}

Farmers were asked whether the farm belonged to them or not. According to Table 3, majority, 75 percent, of farmers owned the farms while 25 percent of respondents called themselves tenants. The tenants manage the farms and proceeds are shared equally or on agreed formular between the farm owners and the tenants at the end of the farming season. Since most of the farms were managed by the owners, this shows that long-term investment could be made on the farms.

\subsection{Perceptions of Climate Change by Cocoa Farmers}

A necessary prerequisite for adaptation is perception. Respondents were asked about their perception on climate change over the last 5 years. The elements of climate that farmers commented upon include temperature, rainfall and wind. 
Table 4: Distribution of cocoa farmers by perception on climate change

\begin{tabular}{lcc}
\hline \multicolumn{1}{c}{ Change } & Frequency* & Percentage \\
\hline Increase in Temperature & 120 & 75 \\
Decrease in Temperature & 10 & 6.25 \\
Increase in Rainfall & 130 & 81.25 \\
Decrease in Rainfall & 54 & 33.75 \\
Changing in the Timing of the Rain & 150 & 93.75 \\
Changing in the Direction of the Wind & 140 & 87.50 \\
Nothing has changed & 5 & 3.12 \\
\hline
\end{tabular}

*Multiple choices allowed

Table 4 reveals the different forms of climatic change that had been observed by the cocoa farmers over the last 5 years. 75 percent of the respondents perceived increase in temperature around their area for over the last 5 years. Just 6.25 percent of the farmers were able to observed decrease in temperature. Also 81.25 percent noticed change in climatic condition as increase in rainfall while 33.75 percent of the entire respondents interviewed observed decrease in temperature. 150 farmers constituting about 93.75 percent perceived change in the timing of the rain. Also, 87.50 percent noticed change in the direction of the wind and few 3.12 percent of them did not detect any change in the condition of climate in the study area. The result shows that most of the respondents noticed climate change in their area.

\subsection{Cocoa Farmers' Adaptation Strategies to Climate Change}

Adaptation to climate change is a two-stage process. The first stage involves the perception of the change by the farmers while at the second stage he/she decides to or not to adopt a particular measure. Only those respondents who perceive climate change will consider the need to adapt to it. Adaptations are the necessary interventions needed to manage the losses or take advantage of the opportunities presented by climate change (IPCC, 2001). The assessment of adaptation measures of cocoa farmers is necessary in order to make available information that will be used to formulate policies that enhance adaptation as away for managing risks associated with climate change in cocoa production.

In response to climate change, especially rainfall and temperature, the key adaptation strategies adopted by Ondo State cocoa farmers include the use of improved variety, use disease tolerant seeds and seedlings, sought off-farm employment, land and water management practices, irrigation, prayer and ritual offerings, planting different varieties, shading and sheltering techniques, use of weather insurance and change planting dates. In the study area, respondents were allowed to mention the number of adaptation measures used on their farms.

Table 5 shows that 58.75 percent of farmers used improved variety of cocoa on their farms in order to adapt to climate change. The use of disease tolerant seeds and seedlings were employed by about 46.88 percent while just 20.63 percent sought off-farm employment in order to adapt to climate change. The majority, 134 farmers constituting about 83.75 percent adopted land and water management practices such as removal of unwanted bush, intercropping, cover crops, green manure and mulching as adaptation measures to climate change.

Table 5: Distribution of respondents by adaptation strategies adopted

\begin{tabular}{lcc}
\hline \multicolumn{1}{c}{ Adaptation strategy } & Frequency $^{*}$ & Percentage \\
\hline Improved variety & 94 & 58.75 \\
Disease tolerant seeds \& seedlings & 75 & 46.88 \\
Sought off-farm employment & 33 & 20.63 \\
Land and water management practices & 134 & 83.75 \\
Prayer and ritual offerings & 110 & 68.75 \\
Planting different varieties & 89 & 55.63 \\
Shading \& sheltering techniques & 117 & 73.13 \\
Insurance & 10 & 6.25 \\
Change planting dates & 124 & 77.50 \\
Irrigation & 3 & 1.88 \\
No adaptation/Did nothing & 26 & 16.25 \\
\hline
\end{tabular}

*Multiple choices allowed

Also, those that embraced prayer to God and ritual offerings to idols for favourable climatic conditions were 68.75 percent. Planting different varieties of cocoa seedlings was carried out to adapt to climate change by 55.63 percent of the 
respondents. Crop insurance policy on cocoa was adopted by few farmers (6.25 percent). Shading and sheltering techniques were used by large number of farmers (73.13 percent) while changing of seedlings planting dates technique was employed by 77.50 percent. The use of irrigation on farm was espoused to adapt to climate change by just 3 farmers constituting 1.88 percent. Some farmers (16.25\%) did nothing to adapt to change in climate parameters. Most of the cocoa farmers that did not take to any adaptation strategy gave lack of fund as reason.

Various types of adaptation strategies adopted by cocoa farmers in the study area shows that the level of climate change perception is high. This implies that in order to remain in farming and sustain livelihood, cocoa farmers are expected to adapt to any climate change that occur in his/her local environment.

Table 6: Heckman's results for determinants of respondents' perception and adaptation to climate change

\begin{tabular}{lcccc}
\multicolumn{1}{c}{ Variable } & \multicolumn{2}{c}{ Coefficient } & \multicolumn{2}{c}{ Standard error } \\
\hline & Perception & Adaptation & Perception & Adaptation \\
Age & $0.941^{* * *}$ & $0.086^{* *}$ & 0.261 & 0.041 \\
Education & $0.767^{* * *}$ & $0.387^{* * *}$ & 0.256 & 0.110 \\
Farming Experience & $0.097^{* *}$ & $1.341^{* * *}$ & 0.048 & 0.489 \\
Gender & -0.251 & 0.493 & 0.157 & 0.335 \\
Marital Status & 0.496 & 0.059 & 0.317 & 0.037 \\
Household Size & $0.091^{* *}$ & 0.191 & 0.035 & 0.119 \\
Farm Size & $0.845^{* * *}$ & $0.713^{*}$ & 0.244 & 0.375 \\
Access to Extension services & $0.074^{*}$ & $0.873^{* * *}$ & 0.041 & 0.225 \\
Access to Credit & -0.965 & $1.201^{* * *}$ & 0.615 & 0.429 \\
Distance to Input Purchasing Market & $-0.089^{*}$ & -0.449 & 0.047 & 0.286 \\
Training on Climate Change & 0.779 & $-1.021^{* *}$ & 0.484 & 0.516 \\
Off-farm Work & -1.340 & -0.542 & 0.912 & 0.311 \\
\hline
\end{tabular}

*,**, and ${ }^{\star \star \star}$ signify significant at $10 \%, 5 \%$, and $1 \%$ probability level respectively

\subsection{Determinants of Perception to Climate Change.}

In order to know the factors that determine the perception status of respondents to climate change, twelve explanatory variables were used. The results according to table 6 show that out of the 12 explanatory variables, 7 variables (age, education, farming experience, household size, farm size, access to extension services, and distance to farm input purchasing market) significantly affected the perception status of farmers while 5 variables (gender, marital status, access to credit, training on climate change and off-farm work ) did not. 3 variables (age, education and farm size), 2 variables (farming experience and household size) and 2 variables (access to extension services and distance to farm input purchasing market) influenced the farmers' perception status at $1 \%, 5 \%$ and $10 \%$ level of significances respectively. In addition, 8 explanatory variables (age, education, farming experience, marital status, household size, farm size, access to extension services and training on climate change) affected the perception status of the cocoa farmers to climate change positively while 4 (gender, access to credit, distance to farm input purchasing market and off-farm work) variables influenced it negatively.

The implication of this result is that farmers that are of age would describe change in climatic conditions correctly than the young farmers. This shows that perception of climate change is directly proportional to the age of the farmers and that older respondents are more efficient in perceiving climate change than the younger respondents. Educational level of farmers also plays a good role in perceiving change in climatic conditions. Table 6 indicates that there is direct relationship between education and ability to know whether climate has changed or not. This implies that farmer's perception of climate change increases with more education. In addition, the positive coefficient of farming experience implies that experienced farmers perceive change in climate better than the inexperienced ones. More also, according to table 6 , the negative sign on the variable gender, shows that female farmers' perception of climate change is better than their male counterparts. The positive sign on the coefficient of marital status variable implies that married respondents perceive climate change in the right direction when compared with those that were single.

Moreover, according to the result in table 6, the perception level of farmer is enhanced when he/she has, a large household size, large farm size or access to extension services. Training on climate change improves the level of farmers' perception to climate change but access to credit reduces the ability of farmer to perceive change in climatic conditions. The more the distance of farmers farm to farm input purchasing market the less the perception level. This may be so because in the market, information is shared among the farmers and farmers with off-farm work may not bother to know whether climate has changed or not. 


\subsection{Determinants of Cocoa Farmer's Adaptation to Climate Change}

In the study area the list of adaptation strategies adopted for climate change by cocoa farmers was compiled and the proportion of adaptation strategies used by each farmer was calculated and used as the dependent variable while the same 12 explanatory variables used for perception of climate change were also used as explanatory variables. The adaptation model was conditioned on the perception to climate change.

Table 6 shows that 9 explanatory variables(age, education, farming experience, gender, marital status, household size, farm size, access to extension service and access to credit) were directly proportional to climate change adaptation level while just 3 independent variables(distance to farm input purchasing market, training on climate change and off-farm work) varied inversely to adaptation level of the farmers. 7 independent variables (age, education, farming experience, farm size, access to extension services, access to credit and training on climate change) were statistically significant. The significances of these variables indicate that they were significantly different from zero and thus very important in determining adaption to climate change. 4 variables (education, farming experience, access to extension services and access to credit), 2 variables (age and training on climate change) and 1 variable (farm size) were significant at 1\%, 5\% and $10 \%$ level of significances respectively.

The result in table 6 on determinants of adaption to climate change implies that as a farmer grows older, his/her level of adaptation to change in climate improves. Farmers adopt more adaptation strategies as his/her age increases. The positive sign on the coefficient of education indicates that education encourages farmers to adopt measures that would allow them to adapt to changes in climatic conditions. The positive sign and the significance of farming experience show that the variable is an important factor in determining climate change. Apart from the fact that experience would allow the farmer to know whether changes have occurred in climatic conditions, it also makes him to know the type and number of measures that would be used to adapt to climate change. This shows that the more experienced a farmer is the better in selecting adaptation strategies. Positive sign on gender coefficient shows that male farmers' level of adaptation to climate change is higher than their female counterparts.

Similarly, the positive sign on marital status implies that married farmers' adaptation to climate change is better than those that are single. Also the result shows that the rate of adoption of adaptation strategies to climate change by farmers with large household size is higher and better. This may be so because those with large family size are always conscious of what will destabilize their ways of living. According to Tesso et al.(2012) farm size is associated with greater wealth which can increase adaptation to change in climatic conditions. The implication of the result in table 6 on farm size is that farmers with large farm size would take up more adaptation strategies when compared to farmers with small farm size. In addition, the result indicates that access to information on farming and climate change through extension services would enhance farmers' adaptation to changes in climatic conditions. Access to credit also encourages and empowers farmers to adopt more measures to curb the menace of climate change. Distance of farm to input purchasing market plays a role in determining adaptation to climate change. Farmers that are far away from the market receive less information on adaptation strategies to climate change because inputs market serves as an avenue for exchanging information with other farmers. One would expect training on climate change to enhance adaptation to climate change but the reverse is the case with our study. The negative sign on the variable off-farm work may be so in a situation when farmers prefer to run to other jobs that are not affected by climate change. Farmers with other sources of income apart from farming would care less about change in climatic conditions.

\section{Conclusion and Recommendations}

The study was carried out in Ondo State, Nigeria to examine the perception of and adaptation to climate change among cocoa farmers. Also, determinants of farmers' level of perception and adaptation to change in climatic conditions were examined. In order to carry out these objectives, descriptive statistics were used to analyse the farmers' socio-economics characteristics while Heckman's two-step procedure was used to identify the determinants of respondents' perception and adaptation to climate change. The analysis revealed that the cocoa farmers' population was ageing and cocoa production in the study area was dominated by men. The household size ranged between 1 and 20 persons while the mean was 8 persons. The majority of the farmers solely made use of hired labour. The average farm size was 7 hectares while the minimum and maximum were 0.4 and 25 hectares respectively. 83.75 percent of cocoa farmers had no access to credit. Most of the respondents noticed climate change in the study area.

In order to adapt to climate change, strategies used by farmers include the use of improved variety, use disease tolerant seeds and seedlings, sought off-farm employment, use land and water management practices, use irrigation, 
prayer and ritual offerings, planting different varieties, use of shading and sheltering techniques, use of weather insurance and change planting dates. 7 variables (age, education, farming experience, household size, farm size, access to extension services, and distance to farm input purchasing market) significantly determined whether or not cocoa farmers perceive climate change while 7 independent variables (age, education, farming experience, farm size, access to extension services, access to credit and training on climate change) significantly determined whether or not they would adapt to it.

Based on the findings of this study and in order to improve the farmers' perception of and adaptation to climate change the following recommendations are suggested:

- Since access to credit is an important factor in climate change adaptation, there is need to make credit available to the farmers for the purchase of farm inputs that are needed for adaptation in order to increase agricultural production and sustain livelihood.

- Also, in order to increase the chance of perceiving and adapting to change in climatic conditions, an effective extension service system should be put in place.

- Finally, for correct perception and adaptation to climate change, literacy level of the farmers should be improved upon.

\section{References}

Anim F, (1999). A note on the adoption of soil conservation measures in the Northern Province of South Africa. Journal of Agricultural Economics 50(2): 336-45.

Anim-Kwapong, G., Frimpong, E. (2005).'Vulnerability of agriculture to climate change impact of climate change on cocoa production.'Accra, Ghana.

Bandiera 0 \& Rasul I, (2002). Social networks and technology adoption in northern Mozambique. CEPR (Center for Economic Policy Research) Discussion Papers 3341.

Besley T \& Case A,(1993). Modeling technology adoption in developing countries. American Economic Review 83: 396-402.

Birkhaeuser D, Evenson R \& Feder G, (1991). The economic impact of agricultural extension: A review. Economic Development and Cultural Change 39: 607-650.

Brooks, N., W. N. Adger and P. M. Kelly. (2005). The determinants of vulnerability and adaptive capacity at the national level and the implications for adaptation. Global Environmental Change Part A, 15(2), pp.151-163.

Bryan, E., T. T. Deressa, G. A. Gbetibouo and C. Ringler. (2009). Adaptation to climate change in Ethiopia and South Africa: options and constraints. Environmental Science \& Policy, 12(4), pp.413-426.

Business Monitor International, (2013) 'Nigeria Agribusiness Report Q3 2013'.

Holloway G, Shankar B \& Rahman S, (2002). Bayesian spatial probit estimation: A primer and an application to HYV rice adoption. Agricultural Economics 27: 383-402.

ICCO, (2009). Factor which affect productivity of cocoa. Westgate House, Ealing, London W5 1YY, UK.

IPCC (2001). Climate change (2001): Impact Adaptation and vulnerability. Cambridge University press, Cambridge.

IPCC. (2012). Managing the Risks of Extreme Events and Disasters to Advance Climate Change Adaptation. A Special Report of Working Groups I and II of the Intergovernmental Panel on Climate Change. Cambridge, UK: Cambridge University Press.

Knight J, Weir S \& Woldehanna T, (2003). The role of education in facilitating risk-taking and innovation in agriculture. Journal of Development Studies 39: 1-22.

Maddison D. (2006). The perception of and adaptation to climate change in Africa. CEEPA. Discussion Paper No. 10. Centre for Environmental Economics and Policy in Africa. Pretoria, South Africa:University of Pretoria.

Muhammad -Lawal, A., Omotesho, O.A. and Falola, A.(2009): "Technical Efficiency of Youth Participation in Agriculture: A case study of the Youth in Agriculture Programme in Ondo State, South Western Nigeria". Nigerian Journal of Agriculture,Food and Evironmental 5(1): 20-26.

Oyekale, A. S. and K. E. Gedion. (2012). Rural households' vulnerability to climate related Income shocks and adaption options in central Malawi. Journal of Food Agriculture \& Environment, 10(3-4), pp.1505-1510.

Reilly J, (1999). What does climate change mean for agriculture in developing countries? A comment on Mendelsohn \& Dinar. World Bank Research Observer 14: 295-305.

Tesso Gutu, Bezabih Emana and Menguistu Ketema. (2012). Econometric analysis of local level perception, adaptation and coping strategies to climate change induced shocks in North Shewa, Ethiopia. International Research Journal of Agricultural Science and Soil Science Vol. 2(8) pp. 347-363.

The Sun Newspaper (2013) 'Contribution of Cocoa to Nigeria's Economy in 2012

Workineh Kalbessa (2007). Climate change impacts and indigenous coping strategies in Africa. Greifswald University, UK. 